\title{
TRANSHIATAL ESOPHAGECTOMY IN SQUAMOUS CELL CARCINOMA OF THE ESOPHAGUS: WHAT ARE THE BEST INDICATIONS?
}

\author{
Esofagectomia transhiatal no carcinoma de células escamosas do esôfago: Quais são suas melhores indicações? \\ Felipe Monge VIEIRA ${ }^{1 \oplus}$, Marcio Fernandes CHEDID ${ }^{1,2 \odot}$, Richard Ricachenevsky GURSKI ${ }^{1,2}{ }^{2}$, Carlos \\ Cauduro SCHIRMER ${ }^{2 \oplus}$, Leandro Totti CAVAZZOLA ${ }^{1,3}{ }^{\circ}$, Ricardo Vitiello SCHRAMM $^{1}{ }^{\oplus}$, André Ricardo \\ Pereira ROSA $^{2 \oplus}$, Cleber Dario Pinto KRUEL ${ }^{1,2 \odot}$
}

\begin{abstract}
Background: Southern Brazil has one of the highest incidences of esophageal squamous cell carcinoma in the world. Transthoracic esophagectomy allows more complete abdominal and thoracic lymphadenectomy than transhiatal. However, this one is associated with less morbidity. Aim: To analyze the outcomes and prognostic factors of squamous esophageal cancer treated with transhiatal procedure. Methods: All patients selected for transhiatal approach were included as a potentially curative treatment and overall survival, operative time, lymph node analysis and use of neoadjuvant therapy were analyzed. Results: A total of 96 patients were evaluated. The overall 5 -year survival was $41.2 \%$. Multivariate analysis showed that operative time and presence of positive lymph nodes were both associated with a worse outcome, while neoadjuvant therapy was associated with better outcome. The negative lymph-node group had a 5 -year survival rate of $50.2 \%$. Conclusion: Transhiatal esophagectomy can be safely used in patients with malnutrition degree that allows the procedure, in those with associated respiratory disorders and in the elderly. It provides considerable long-term survival, especially in the absence of metastases to local lymph nodes. The wider use of neoadjuvant therapy has the potential to further increase long-term survival.
\end{abstract}

HEADINGS: Squamous cell carcinoma of head and neck. Esophagus. Esophagectomy. Neoadjuvante therapy.

RESUMO - Racional: O sul do Brasil tem uma das maiores incidências de carcinoma epidermoide do esôfago no mundo. A esofagectomia transtorácica permite linfadenectomia abdominal e torácica mais completa do que a transhiatal. No entanto, esta está associado à menor morbidade. Objetivo: Analisar os desfechos e fatores prognósticos do câncer epidermoide do esôfago que foram tratados com procedimento transhiatal. Métodos: Foram incluídos todos os pacientes selecionados para abordagem transhiatal como tratamento potencialmente curativo correlacionando sobrevida geral, tempo operatório, análise de linfonodos e uso de terapia neoadjuvante. Resultados: Foram avaliados 96 pacientes. A sobrevida geral em cinco anos foi de $41,2 \%$. A análise multivariada mostrou que o tempo operatório e a presença de linfonodos positivos foram associados a pior resultado, enquanto a terapia neoadjuvante contribuiu para melhor resultado. $\mathrm{O}$ grupo de linfonodos negativos teve taxa de sobrevivência em cinco anos de 50,2\%. Conclusão: A esofagectomia transhiatal pode ser empregada com segurança em pacientes que apresentem desnutrição com grau que permita o procedimento, nos com distúrbios respiratórios associados e nos idosos. Proporciona sobrevida em longo prazo considerável, especialmente na ausência de metástases para linfonodos locais. O uso mais amplo da terapia neoadjuvante tem o potencial de aumentar ainda mais a sobrevida em longo prazo.

DESCRITORES: Carcinoma de células escamosas do esôfago. Esôfago. Esofagectomia. Terapia neoadjuvante.

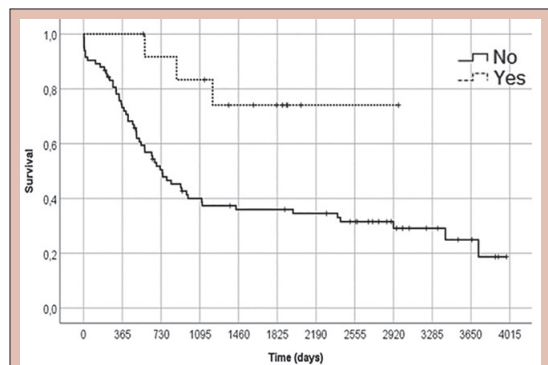

Overall survival in patients who underwent transhiatal esophagectomy submitted or not to neoadjuvant therapy

\section{Central message}

Transhiatal esophagectomy can be safely used in patients with lower performance status and especially in the absence of metastases to local lymph nodes.

\begin{tabular}{|l|}
\hline Perspective \\
This sudy demonstrates feasibility of the transhiatal \\
approach in the treatment of esophageal squamous \\
cell carcinoma. Transhiatal esophagectomy is \\
associated with less morbidity when compared with \\
the transthoracic approaches and may be associated \\
with a considerable long-term survival in selected \\
patients and those submitted to neoadjuvant therapy.
\end{tabular}

From the ${ }^{1}$ Programa de Pós-Graduação em Ciências Cirúrgicas, Universidade Federal do Rio Grande do Sul, Porto Alegre, RS, Brasil; ${ }^{2}$ Departamento de Cirurgia do Aparelho Digestivo, Universidade Federal do Rio Grande do Sul, Porto Alegre, RS, Brasil; ${ }^{3}$ Departamento de Cirurgia Geral, Universidade Federal do Rio Grande do Sul, Porto Alegre, RS, Brasil ('Postgraduate Program in Surgical Sciences, Federal University of Rio Grande do Sul, Porto Alegre, RS, Brazil; '2Department of Digestive Surgery, Federal University of Rio Grande do Sul, Porto Alegre, RS, Brazil; ${ }^{3}$ Department of General Surgery, Federal University of Rio Grande do Sul, Porto Alegre, RS, Brazil).

How to cite this article: Vieira FM, Chedid MF, Gurski RR, Schirmer CC, Cavazzola LT, Schramm RV, Rosa ARP, Kruel CDP. Transhiatal esophagectomy in squamous cell carcinoma of the esophagus: what are the best indications? ABCD Arq Bras Cir Dig. 2020;33(4):e1567. DOI: /10.1590/0102-672020200004e1567

Correspondence:

Felipe Monge Vieira

E-mail: felipemongevieira@gmail.com
Financial source: Fundação de Incentivo à Pesquisa do Hospital de Clínicas de Porto Alegre and financed in part by the Coordenação de Aperfeiçoamento de Pessoal de Nível Superior - Brasil (CAPES) - Finance Code 001

Conflict of interest: none

Received for publication: 14/09/2020

Accepted for publication: 04/11/2020 


\section{INTRODUCTION}

$\mathrm{O}$ ne of the world ss highest incidences of esophageal squamous cell carcinoma (ESCC) is detected in the state of Rio Grande do Sul, Brazil 6 . Most of this population has a low income. Surgical treatment is the standard of care for management with curative intent. Despite advances in surgical techniques and postoperative care in recent years, esophagectomy remains associated with significant morbidity ${ }^{31}$.

Transthoracic esophagectomy (TTE) with two or three operative fields allows for a more complete thoracic lymphadenectomy than transhiatal esophagectomy (THE) does. Although there is no randomized study or systematic review proving oncologic superiority comparing them, the former is considered the standard of care for esophageal cancers. In contrast, in THE patients are spared from thoracotomy and a potential decrease in perioperative morbidity and operative time is expected to occur ${ }^{10,25,28,31}$. Potential disadvantages include the need for blind dissection, especially when lesions are located in upper and middle thoracic esophagus, which may lead to hemorrhage and compromise oncological status ${ }^{31}$. Therefore, it is generally reserved for patients with benign esophageal diseases and in the ones with esophageal cancer whose performance status is lower due to malnutrition or chronic obstructive pulmonary disease.

In contrast to esophageal adenocarcinoma, which usually occurs in well-nourished patients with a history of Barrett's syndrome secondary to gastroesophageal reflux disease ${ }^{1}$, ESCC usually occurs in malnourished patients secondary to long-term heavy smoking ${ }^{10,25,28,31}$. THE is generally associated with fewer pulmonary complications, and demands less intensive care measures. As the vast majority of our patients are ESCC rather than esophageal adenocarcinoma, we have adopted the policy of performing THE in all patients with malnutrition and respiratory disorders, as well as in older.

There are few prior studies evaluating the outcomes of THE in ESCC and so, the aim of this research was to analyze its results and prognostic factors.

\section{METHODS}

This study was approved by the Research Ethics Committee of Hospital de Clínicas de Porto Alegre (GPPG HCPA 17-0601). Informed consent was waived due to the retrospective, observational design. It included all patients who underwent elective THE as treatment for ESCC at a single center from 2005 to 2017. A gastric tube, by open and laparoscopic technique, was used to reconstruct the gastrointestinal tract - esophagogastrostomy. Data were obtained by reviewing medical records and data from the State Department of Health. Overall survival and specific survival rates were evaluated.

\section{Operative technique}

The operative technique utilized is similar to the described by Orringer ${ }^{25}$. A manual end-to-side esophagogastrostomy with absorbable sutures is performed. The lower edge of the incision remains open for visualization of the viability of the gastric tube and surveillance for anastomotic leaks. A sentinel Penrose drain is placed by counter-incision near the lower edge of the operative wound. Immediate postoperative care is carried out in the intensive care unit. Oral contrastenhanced examination is performed on the $7^{\text {th }}$ postoperative day to assess the anastomosis.

\section{Statistical analysis}

The primary outcome was postoperative mortality at any time. The secondary was mortality during the first 90 postoperative days. Patients were followed until the end of the study period or until death. The overall survival rate was measured from the date of surgery to the last day of follow-up (in patients who remained alive) or until the date of death. The descriptive variables of interest were age, gender, skin color, smoking status, alcohol intake, hypertension, type 2 diabetes mellitus, chronic obstructive pulmonary disease, lesion size and location, total number of lymph nodes in the pathological specimen, presence or absence of positive lymph nodes, total number of positive lymph nodes, resection margins, neoadjuvant therapy (NAT), adjuvant treatment, intraoperative splenectomy, intraoperative scheduled esophagostomy, operative time, ASA (American Society of Anesthesiologists) classification, length of stay, Clavien-Dindo index, occurrence of anastomotic leak, and other postoperative complications (e.g., pneumonia, cardiac arrhythmia). Survival was analyzed using the Kaplan-Meier method. The log-rank test was used for comparison between different groups. Categorical variables were compared using the chi-square test. Continuous variables were analyzed with the Mann-Whitney U-test or T-test as appropriate. Univariate analysis for each of the two outcomes was performed using the Cox proportional regression method. For the primary and secondary outcomes, the variables considered statistically significant in univariate analysis $(p<0.05)$ were entered into Cox multivariate proportional regression models to identify risk factors independently associated with the two study outcomes. For all analyzes, $\mathrm{p}$-values $<0.05$ were considered statistically significant. Analyses were performed in SPSS Statistics 18.0 for Windows.

\section{RESULTS}

The characteristics of the 96 patients included are presented in Table 1. Thirteen (13.5\%) underwent NAT. The neoadjuvant protocol included chemotherapy with carboplatin and paclitaxel for five weeks plus radiotherapy ( $41.4 \mathrm{~Gy}$, divided into 23 fractions). Surgery was planned to occur six to eight weeks after neoadjuvant treatment was finished (Table 1).

TABLE 1 - Demographic profile of patients undergoing transhiatal esophagectomy for esophageal squamous cell carcinoma $(n=96)$

\begin{tabular}{|l|c|}
\hline Gender & 68 men $(70.8 \%)$ \\
\hline Age & $59.1(29-84) \pm 9.8$ \\
\hline Skin color & White: $87(90.6 \%)$ \\
& Black: $7(7.3 \%)$ \\
\hline ASA & Brown: $2(2.1 \%)$ \\
\hline Neoadjuvant treatment & ASA 2: $74(77.1 \%)$ \\
\hline Adjuvant treatment (1 missing) & ASA 3: $22(22.9 \%)$ \\
\hline Smoking (previous or active) (2 missing) & $13(13.5 \%)$ \\
\hline Alcoholism (previous or active) & $8(8.4 \%)$ \\
\hline Hypertension & $69(73.4 \%)$ \\
\hline Type 2 diabetes mellitus & $33(34.4 \%)$ \\
\hline Chronic obstructive pulmonary disease & $26(27.1 \%)$ \\
\hline Heart disease & $4(4.2 \%)$ \\
\hline
\end{tabular}

Pathological variables are described in Table 2. Postoperative outcomes are seen in Table 3. On univariate analysis, positive margins $(\mathrm{HR}=2.395,95 \% \mathrm{Cl}=1.337-4.289, \mathrm{p}=0.003)$, positive lymph nodes $(\mathrm{HR}=2.373,95 \% \mathrm{Cl}=1.420-3.964, \mathrm{p}<0.001)$, size of the tumor $(\mathrm{HR}=1.014 ; 95 \% \mathrm{Cl}=1.002-1.027, \mathrm{p}=0.023)$, and operative time $(\mathrm{HR}=1.003,95 \% \mathrm{Cl}=1.001-1.005, \mathrm{p}=0.005)$ were all associated with increased overall mortality. Conversely, NAT $(\mathrm{HR}=0.245 ; 95 \% \mathrm{Cl}=0.076-0.784, \mathrm{p}=0.018)$ was associated with a $76.5 \%$ reduction in overall mortality (Table 4 ). 
TABLE 2 - Pathological variables of patients undergoing transhiatal esophagectomy for esophageal squamous cell carcinoma $(\mathrm{n}=96)$

\begin{tabular}{|c|c|c|c|}
\hline Tumor location (1 missing) & $\begin{array}{c}3 \text { (upper) } \\
\text { (3.2\%) }\end{array}$ & $\begin{array}{c}39 \\
\text { (medium) } \\
(41.1 \%)\end{array}$ & $\begin{array}{c}53 \\
\text { (lower) } \\
\text { (55.8\%) }\end{array}$ \\
\hline Tumor size, cm (2 missing) & $\begin{array}{l}2.94 \pm 18.4 \\
\quad(0-9.5)\end{array}$ & & \\
\hline Median number of lymph nodes & $\begin{array}{c}10.8 \pm 5.7 \\
(0-27)\end{array}$ & & \\
\hline $\begin{array}{l}\text { Patients with positive lymph nodes } \\
\text { Laparoscopy }\end{array}$ & $\begin{array}{c}37(38.5 \%) \\
2(2 \%)\end{array}$ & & \\
\hline Resection margin (1 missing) & R0 76 (80\%) & $\begin{array}{l}\text { Not R0 } \\
19(20 \%)\end{array}$ & \\
\hline
\end{tabular}

TABLE 3 - Postoperative complications in patients undergoing transhiatal esophagectomy for esophageal squamous cell carcinoma( $\mathrm{n}=96)$

\begin{tabular}{|c|c|c|c|}
\hline Complication & \multicolumn{3}{|c|}{ n (\%) } \\
\hline Pneumonia & \\
\hline Anastomotic leak & & & \\
\hline Cardiac arrhythmia & \multicolumn{3}{|c|}{$\begin{array}{c}41(43.2 \%) \\
6(6.3 \%)\end{array}$} \\
\hline Splenectomy & \multicolumn{3}{|c|}{$5(5.2 \%)$} \\
\hline $\begin{array}{l}\text { Need for esophagostomy for } \\
\text { delayed cervical anastomosis }\end{array}$ & \multicolumn{3}{|c|}{11 (11.5\%) } \\
\hline Mediastinitis & \multicolumn{3}{|c|}{$5(5.2 \%)$} \\
\hline Chilous leak & \multicolumn{3}{|c|}{$4(4.3 \%)$} \\
\hline Gastric tube necrosis & \multirow{2}{*}{\multicolumn{3}{|c|}{$\begin{array}{l}2(2.1 \%) \\
44(45.8)\end{array}$}} \\
\hline \multirow[t]{2}{*}{ Clavien-Dindo $>2$} & & & \\
\hline & $\begin{array}{c}\text { Mean } \\
\text { (Std. Dev.) }\end{array}$ & Median [IQR] & $\min -\max$ \\
\hline $\begin{array}{l}\text { Operative time } \\
\text { (min) (1 missing) }\end{array}$ & $\begin{array}{l}253.7 \\
(101.5)\end{array}$ & 231 [197; 289] & $132-740$ \\
\hline Length of stay & $\begin{array}{r}24.8 \\
(27.7)\end{array}$ & $17[12 ; 23]$ & $3-201$ \\
\hline
\end{tabular}

TABLE 4 - Univariate analysis of overall survival in patients undergoing transhiatal esophagectomy for esophageal squamous cell carcinoma $(n=96)$

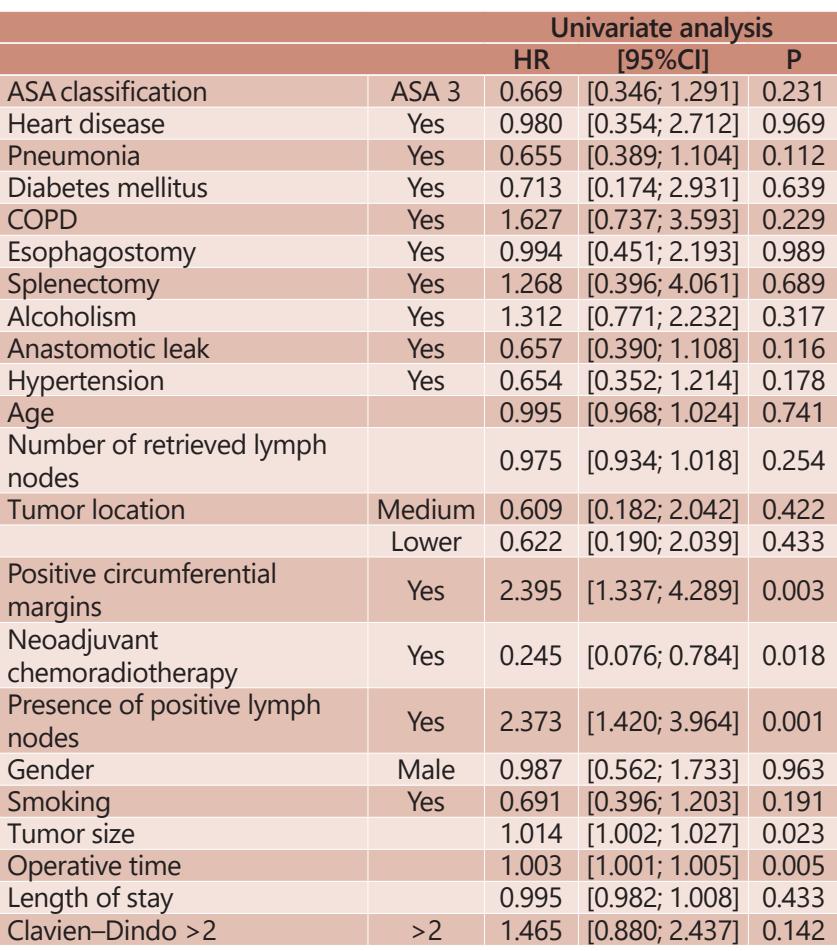

In the multivariate analysis for overall survival, positive lymph nodes $(\mathrm{HR}=2.240,95 \% \mathrm{Cl}=1.332-3.769, \mathrm{p}=0.002)$ and prolonged operative time $(\mathrm{HR}=1.003,95 \% \mathrm{Cl}=1.000-1.005, \mathrm{p}=0.019)$ were the only predictors of increased mortality. Again, NAT was protective, with a nearly $70 \%$ reduction in mortality $(\mathrm{HR}=0.299,95 \% \mathrm{Cl}=0.092$ -
0.970, $p=0.044$, Table 5). Univariate analysis showed no factors associated with increased 90-day mortality (Table 6).

TABLE 5- Multivariate analysis of overall survival in patients undergoing transhiatal esophagectomy for esophageal squamous cell carcinoma $(n=96)$

\begin{tabular}{l|c|c|c|c|}
\hline & \multicolumn{4}{c}{ Multivariable analysis } \\
\hline & \multicolumn{1}{c}{ HR } & {$[95 \% \mathrm{Cl}]$} & $\mathrm{p}$ \\
\hline Neoadjuvant chemoradiotherapy & Yes & 0.299 & {$[0.092 ; 0.970]$} & 0.044 \\
\hline $\begin{array}{l}\text { Presence of positive lymph nodes } \\
\text { Oes }\end{array}$ & 2.240 & {$[1.332 ; 3.769]$} & 0.002 \\
\hline $\begin{array}{l}\text { Operative time } \\
\text { * Cox regression }\end{array}$ & & 1.003 & {$[1.000 ; 1.005]$} & 0.019 \\
\hline
\end{tabular}

TABLE 6 - Univariate analysis for 90-day survival $(n=96)$

\begin{tabular}{|c|c|c|c|}
\hline & $\begin{array}{l}\text { Risk } \\
\text { Ratio }\end{array}$ & $95 \% \mathrm{Cl}$ & $p$ \\
\hline ASA classification" ${ }^{\#}$ & 0.909 & $0.183-4.504$ & 0.907 \\
\hline Heart disease & 0.625 & $0.77-5.078$ & 0.660 \\
\hline Pneumonia & 41.923 & $0.105-16691.986$ & 0.221 \\
\hline Diabetes & 2.223 & $0.273-18.076$ & 0.455 \\
\hline COPD & 0.301 & $0.061-1.494$ & 0.142 \\
\hline Esophagostomy & 0.890 & $0.110-7.238$ & 0.914 \\
\hline Splenectomy & 0.355 & $0.044-2.888$ & 0.333 \\
\hline Alcoholism & 2.157 & $0.435-10.690$ & 0.346 \\
\hline Anastomotic leak & 53.586 & $0.173-16607.237$ & 0.174 \\
\hline Hypertension & 0.727 & $0.174-3.042$ & 0.662 \\
\hline Age & 1.000 & 0.928-1.077 & 0.996 \\
\hline Number of retrieved lymph nodes & 0.997 & $0.882-1.126$ & 0.957 \\
\hline Tumor location & & & $0.489^{*}$ \\
\hline $\begin{array}{l}\text { Positive circumferential } \\
\text { resection margins }\end{array}$ & 0.605 & $0.117-3.120$ & 0.548 \\
\hline Neoadjuvant therapy & 25.316 & $0.004-152096.807$ & 0.467 \\
\hline Presence of positive lymph nodes & 0.628 & $0.157-2.510$ & 0.510 \\
\hline Gender & 1.601 & $0.800-3.201$ & 0.183 \\
\hline Smoking & 1.426 & $0.288-7.066$ & 0.664 \\
\hline Tumor size & 1.026 & 0.997-1.055 & 0.80 \\
\hline Operative time & 0.999 & 0.991-1.007 & 0.764 \\
\hline Clavien-Dindo $>2$ & 0.12 & $0.000-3.713$ & 0.130 \\
\hline
\end{tabular}

The 90 -day survival was $91.7 \%$, while the 1 -year, 3-year, and 5 -year survival rates were $76.8 \%, 46 \%$, and $41.2 \%$, respectively. The median survival was 30.5 months (Figure 1A). Excluding the eight patients who died in the first 90 postoperative days, the 5 -year survival rate was 45\% (Figure 1B).

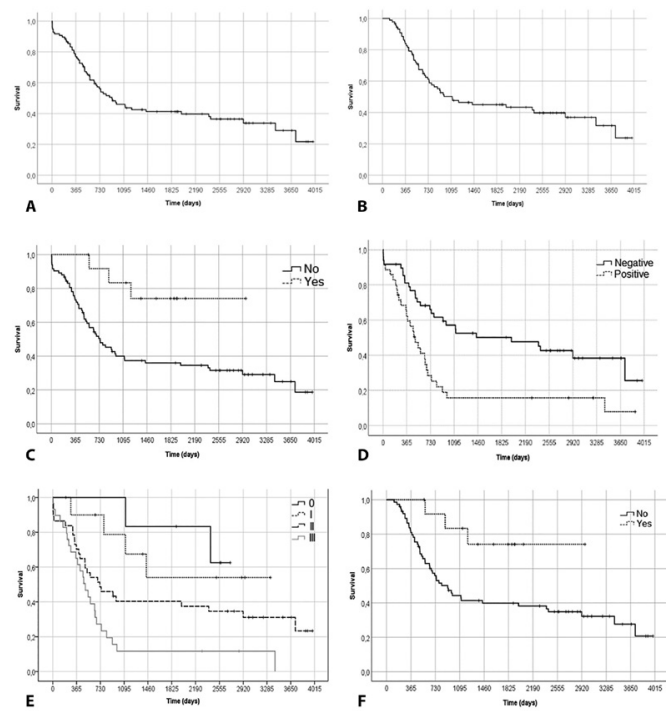

FIGURE 1 - A) Overall survival; B) survival excluding short-term death; C) overall survival in patients submitted or not to neoadjuvant therapy; D) upperfront esophagectomy survival according positive and negative lymph-nodes; E) survival according to TNM stage; F) survival in patients submitted or not to neoadjuvant therapy excluding short-term death. 
Patients who did not receive NAT $(n=83)$ had 1-year, 3 -year, and 5 -year survival rates of $73.1 \%, 40 \%$, and $36 \%$, respectively. Conversely, NAT patients $(n=13)$ had 1-year, 3-year, and 5 -year survival of $100 \%, 83.3 \%$, and $74.1 \%$ respectively $(p=0.01$, Figure $1 C)$.

In the non-NAT group, 35 patients (42\%) had positive lymph nodes and 48 (58\%) did not. Among those with positive nodes, median survival was 16.6 months and the 5 -year survival rate was $15.8 \%$. On the other hand, the negative lymph-node group had a median survival of 65.8 months and a 5-year survival rate of $50.2 \%(p=0.001$, Figure 1D).

The non-NAT group was separated into stages, according to the $7^{\text {th }}$ edition of the AJCC ${ }^{29}$. Stages II and III comprised 37 (45\%) and 29 (35\%) patients, respectively. For stage II patients, median survival was 24 months and 5 -year survival was $40.4 \%$. For stage III, median survival was 16.6 months and 5 -year survival was $11.7 \%$ (Figure 1E). Five-year survival excluding 90 -day deaths was also analyzed; non-NAT patients achieved a rate of $39.8 \%$, while in the NAT group $74.1 \%$ survived ( $p=0.01$, Figure 1F).

\section{DISCUSSION}

A large number of studies analyzing the results of surgical treatment of ESCC involve cohorts that also comprise esophageal adenocarcinoma ${ }^{3,9,15,18,23,33,36,37,38}$. Moreover, several studies do not discriminate the results of esophagectomy by tumor type (ESCC vs. esophageal carcinoma). Most papers focusing exclusively on ESCC describe outcomes of TTE rather than THE $21,22,39$. Moreover, most of these studies include only Asians. Ma et al. ${ }^{21}$ analyzed 695 patients who underwent TTE for ESCC in China. As here, most of the sample was composed of male smokers. In the medical literature, overall survival for TTE in the treatment of ESCC ranges from $17.4 \%$ to $41 \% 11,17,19,40$

Our study analyzes the outcomes of THE employed exclusively in the treatment of ESCC. A total of 96 consecutive cases were included. Although only $16.6 \%$ had early tumors, an overall 5 -year survival rate of $41.2 \%$ was reached. In studies which reported the results of THE for treatment of ESCC $3,8,11,13,17,19,25,5$-year survival was highly variable (9-48\%). Goldminc et al. ${ }^{12}$ published the first prospective randomized study comparing THE vs. TTE. Thirty-two patients underwent $\mathrm{THE}$, achieving a 3-year survival close to $30 \%$, which was similar to the group undergoing TTE. Bogoevski et al. ${ }^{2}$ reported the results of 22 patients with early ESCC ( $\mathrm{T} 1 \mathrm{a}, \mathrm{T} 1 \mathrm{~b}$, and high-grade dysplasia) treated with $\mathrm{THE}$; the 5 -year survival rate was $47.6 \%$, similar to that described in our study. Therefore, the outcomes achieved with THE for the treatment of ESCC in our study are comparable to the best previous published results.

As expected and reported in the literature, lymph node involvement was associated with worse prognosis in our sample $e^{3,19,20,32}$. Multivariable analysis revealed a 2.2-fold increase in overall mortality with metastasis to local lymph nodes. Conversely, circumferential resection margin had no statistically significant risk relationship. This may have been due to the small number of analyzed patients, possibly resulting in type II error.

In the present study, the 5-year survival among lymph node-negative was $53.8 \%$, whereas the lymph node-positive was $20.7 \%$. Evaluating the outcomes in this same objective, Yekebas et al. reported a 5 -year survival close to $50 \%{ }^{40}$. Lieberman et al. ${ }^{20}$ evaluated 258 patients with esophageal and esophagogastric junction neoplasia who underwent curative esophagogastrectomy (ESCC $n=124)$ and observed that $\mathrm{T}$-stage, $\mathrm{N}$-stage, and number of affected lymph nodes were independent predictors of overall survival, while histological type was not significant. In a recent review, $\mathrm{Cho}^{5}$ evaluated the performance of endoscopic ultrasound in the evaluation of lymph node involvement by esophageal cancer and reported up to $99 \%$ accuracy of preoperative endoscopic ultrasound with fine needle aspiration in evaluation of metastatic involvement of local lymph nodes.

In this study, the 5-year survival of patients undergoing upfront surgery was $36 \%$. In parallel, the 13 patients who received NAT (the most recent group in our series) had a 5 -year survival of $74.1 \%$. Van Hagen et al. ${ }^{35}$ observed that patients with esophageal and esophagogastric junction neoplasia (adenocarcinoma, ESCC, and undifferentiated carcinoma) who underwent NAT had higher R0 resection rates, important complete pathological response rates (49\% for ESCC), and longer long-term survival compared to patients undergoing surgical treatment alone. In the ESCC subgroup, 5 -year survival in the NAT group reached about 55\%, while the group undergoing exclusive surgical treatment had a survival of approximately $35 \%$ over the same period.

The incidence of anastomotic leak in THE is quite variable in the literature. A systematic review ${ }^{2}$ on esophagectomy complications observed that, although anastomotic leak is the most commonly described complication following esophagectomy, more than 22 different definition criteria for it were utilized. Although efforts are underway to universalize the diagnosis of surgical complications related to esophagectomy, most studies do not present homogeneity in their diagnostic criteria ${ }^{2,26}$. Nederlof et al..$^{24}$ evaluated the incidence of anastomotic leak in 123 patients undergoing esophagectomy for malignant neoplasia. THE and TTE with end-to-end and end-to-side reconstruction techniques were analyzed. In both groups, anastomosis was constructed in the cervical region using a single continuous layer of monofilament suture. The end-to-end technique had a leak ratio of $22 \%$, whereas end-to-side reconstruction 41\%. Among 96 THE with manual end-to-side esophagogastrostomy using absorbable sutures, our sample had a $43 \%$ incidence of leakage, similar to that of the end-to-side group of the aforementioned study. Two-step anastomosis has been suggested as a potential strategy to minimize this complication and reduce surgical morbidity and mortality ${ }^{14}$

Increased operative time was associated with a modest reduction in survival in the present study. Valsangkar et al. ${ }^{34}$ analyzed 1446 cases of THE between 2010 and 2015 and found that longer operative time in THE was related to higher rates of pneumonia, prolonged intubation, unplanned reintubation, longer hospital stay, septic shock, and mortality.

One limitation of the current study was the absence of a TTE control group. Although some studies have shown long-term survival benefits for TTE over THE in the treatment of ESCC ${ }^{17,19,40}$, three previous systematic reviews failed to demonstrate differences between the two procedures ${ }^{4,16,30}$. Favorable results (5-year survival of $40 \%$ ) were obtained in patients with stage II cancer in the present study. Considering that previous research has revealed no difference in long-term survival between the two esophagectomy techniques, the results reported herein reveal important internal validity ${ }^{3,7,11,12}$. Donohoe et al. ${ }^{7}$ concluded that THE can be an alternative to TTE, especially for patients with significant comorbidities or for the treatment of early-stage carcinoma. However, the authors did not discriminate the results of THE specifically for ESCC. The retrospective nature of our design may have led to measurement biases; however, although our review was retrospective, the data were collected prospectively, which may have attenuated these potential biases.

\section{CONCLUSION}

Transhiatal esophagectomy can be safely used in patients with malnutrition degree that still allows the procedure, in those with associated respiratory disorders and in the elderly. It provides 
considerable long-term survival, especially in the absence of metastases to local lymph nodes. The wider use of neoadjuvant therapy has the potential to further increase long-term survival.

\section{REFERENCES}

1. BarchiLC, Ramos MFKP, DiasAR, Andreollo NA, WestonAC, Lourenço LG, Malheiros CA, Kassab P, Zilberstein B. II Brazilian Consensus on Gastric Cancer by the Brazilian Gastric Cancer Association. ABCD Arq Bras Cir Dig. 2020;33(2):e1514.

2. Blencowe NS, Strong S, McNair AGK, Brookes ST, Crosby T, Griffin SM et al. Reporting of short-term clinical outcomes after esophagectomy: a systematic review. Ann Surg. 2012 Apr;255(4):658-66.

3. Bogoevski D, Bockhorn M, Koenig A, Reeh M, von Loga K, Sauter G, et al. How radical should surgery be for early esophageal cancer? World J Surg. 2011 Jun;35(6):1311-20.

4. Boshier PR, Anderson O, Hanna GB. Transthoracic versus transhiatal esophagectomy for the treatment of esophagogastric cancer: a metaanalysis. Ann Surg. 2011 Dec;254(6):894-906.

5. Cho JW. The Role of Endosonography in the Staging of Gastrointestinal Cancers. ClinEndosc. 2015 Jul:48(4):297-301.

6. Corley DA, Buffler PA. Oesophageal and gastric cardia adenocarcinomas: analysis ofregionalvariation using the Cancer Incidencein Five Continents database. Int J Epidemiol. 2001 Dec;30(6):1415-25

7. Donohoe CL, O'Farrell NJ, Ravi N, Reynolds JV. Evidence-based selective application of transhiatal esophagectomy in a high-volume esophagea center. World J Surg. 2012 Jan;36(1):98-103.

8. Dudhat SB, Shinde SR. Transhiatal esophagectomy for squamous cell carcinoma of the esophagus. DisEsophagus. 1998 Oct 1;11(4):226-30.

9. Ecker BL, Savulionyte GE, Datta J, Dumon KR, Kucharczuk J, Williams $\mathrm{NN}$, et al. Laparoscopic transhiatal esophagectomy improves hospital outcomes and reduces cost: a single-institution analysis of laparoscopic assisted and open techniques. SurgEndosc. 2016 Jun;30(6):2535-42

10. GanesamoniS, KrishnamurthyA.Three-field transthoracicversustranshiatal esophagectomy in the management of carcinoma esophagus-a single-center experience with a review of literature. J GastrointestCancer. 2014 Mar;45(1):66-73.

11. Goan Y-G, Chang H-C, Hsu H-K, Chou Y-P. An audit of surgical outcomes of esophageal squamous cell carcinoma. Eur J CardiothoracSurg. 2007 Mar;31(3):536-44

12. Goldminc M, Maddern G, Le Prise E, Meunier B, Campion JP, Launois B. Oesophagectomybyatranshiatalapproachorthoracotomy:aprospective randomized trial. Br J Surg. 1993 Mar;80(3):367-70.

13. Gupta NM, Jindal R, Prakash O, Gupta R, Bhasin DK. Comparison of the clinical profile and outcome for squamous cell carcinoma and adenocarcinoma of the distal esophagus and cardia in India. SurgToday. 2001;31(5):400-4

14. Gurski RR, Schirmer CC, Toneto JE Jr, Rosa AR, Toniazzo GP, Fasolo GR et al. Delayed cervical anastomosis of the esophagus for esophagea carcinoma. Int Surg. 1997 Jan;82(1):56-9.

15. Gurusamy KS, Pallari E, Midya S, Mughal M. Laparoscopic versus open transhiataloesophagectomy for oesophageal cancer. Cochrane Upper GI and Pancreatic Diseases Group, editor. Cochrane Database Syst Rev. 2016 Mar 31:89:80.

16. Hulscher JBF, Tijssen JGP, Obertop $H$, van Lanschot JJB. Transthoracic versus transhiatal resection for carcinoma of the esophagus: a metaanalysis. Ann ThoracSurg. $2001 \mathrm{Jul}$;22(1):306-13.

17. Junginger T, Gockel I, Heckhoff S. A comparison of transhiatal and transthoracic resections on the prognosis in patients with squamous cell carcinoma of the esophagus. Eur J SurgOncol. 2006 Sep;32(7):749-55.

18. Koide N, Suzuki A, Kitazawa M, Saito H, Miyagawa S. How much length of the distal esophagus is removed by transhiatal approach for squamous cell carcinoma and Barrett's adenocarcinoma in Japanese patients? Hepatogastroenterology. 2011 Nov;58(112):1993-7.

19. Kutup A, Nentwich MF, Bollschweiler E, Bogoevski D, Izbicki JR, Hölscher $\mathrm{AH}$. What should be the gold standard for the surgical component in the treatment of locally advanced esophageal cancer: transthoracic versus transhiatal esophagectomy. Ann Surg. 2014 Dec;260(6):1016-22.
20. LiebermanMD, ShriverCD, BlecknerS,BurtM.Carcinomaoftheesophagus: Prognostic significance of histologic type. J ThoracCardiovascSurg. 1995 Jan:109(1):130-9.

21. Ma Q, Liu W, Long H, Rong $T$, Zhang $L$, Lin $Y$, et al. Right versus left transthoracicapproach forlymph node-negative esophageal squamous cell carcinoma. J CardiothoracSurg. 2015 Sep18;10:123.

22. Matsuda S, Tsubosa Y, Niihara M, Sato H, Takebayashi K, Kawamorita $\mathrm{K}$, et al. Comparison of transthoracic esophagectomy with definitive chemoradiotherapy as initial treatment for patients with esophageal squamouscellcarcinomawhocould toleratetransthoracicesophagectomy. Ann SurgOncol. 2015 Jan 7:22(6):1866-73.

23. Mir MR, Lashkari M, Ghalehtaki R, Mir A, Latif AH. Transhiatal versus Left TransthoracicEsophagectomyforGastroesophageal JunctionCancer; The Impact of Surgical Approach on Postoperative Complications. Middle East J DigDis. 2019 Apr;11(2):104-9.

24. Nederlof N, Tilanus HW, Tran TCK, Hop WCJ, Wijnhoven BPL, de Jonge J. End-to-end versus end-to-sideesophagogastrostomy after esophageal cancer resection: a prospective randomized study. Ann Surg. 2011 Aug:254(2):226-33.

25. OrringerMB, Marshall B, Chang AC, LeeJ, PickensA, Lau CL. Twothousand transhiatal esophagectomies: changing trends, lessons learned. Ann Surg. 2007 Sep;246(3):363-72; discussion 372-4

26. PeraM,LowDE.Consenso paradefinirydaraconocerlascomplicaciones de laesofagectomía:unpasoimportanteparalautilizacióndeunlenguajecomún. CirugíaEspañola. 2015 Nov;93(9):549-51.

27. Perry KA, Funk LM, Muscarella P, Melvin WS. Perioperative outcomes of laparoscopic transhiatal esophagectomy with antegrade esophageal inversion for high-grade dysplasia and invasive esophageal cancer. Surgery. 2013 Oct;154(4):901-7; discussion 907-8.

28. RentzJ, BullD, HarpoleD, BaileyS, NeumayerL, PappasT,etal. Transthoracic versus transhiatal esophagectomy: a prospective study of 945 patients. J Thorac Cardiovasc Surg. 2003 May; 125(5):1114-20.

29. RiceTW, BlackstoneEH, Rusch VW.7thedition oftheAJCCCancerStaging Manual: esophagus and esophagogastric junction. Ann SurgOncol. 2010 Jul;17(7):1721-4.

30. RindaniR,MartinCJ,CoxMR. Transhiatalversus/vor-Lewisoesophagectomy: is there a difference? Aust N Z J Surg. 1999 Mar;69(3):187-94.

31. Schlottmann F, Strassle PD, Patti MG. Transhiatal vs. Transthoracic Esophagectomy: A NSQIP Analysis of Postoperative Outcomes and Risk Factors for Morbidity. J GastrointestSurg. 2017 Nov 12;21(11):1757-63.

32. Takeda FR, Tustumi F, Nigro BC, Sallum RAA, Ribeiro-Junior U, Cecconello I. Transhiatal Esophagectomy is not associated with poor quality lymphadenectomy. ABCD Arq Bras Cir Dig. 2019;32(4):e1475.

33. Takeno S, Takahashi Y, Ono K, Moroga T, Yamana I, Maki K, et al. Surgical resection for cancer located mainly in the lower esophagus. Hepatogastroenterology. 2013 Nov;60(128):1955-60.

34. Valsangkar N, Salfity HVN, Timsina L, Ceppa DP, Ceppa EP, Birdas TJ. Operative time in esophagectomy: Does it affect outcomes? Surgery. 2018 Oct;164(4):866-71.

35. van Hagen P, Hulshof MCCM, van LanschotJJB, Steyerberg EW, van Berge HenegouwenMI,WijnhovenBPL, etal.Preoperativechemoradiotherapyfor esophagealorjunctional cancer.NEnglJMed.2012May31;366(22):2074-84.

36. Vijayakumar M, Burrah R, Hari K, Veerendra KV, Krishnamurthy S. Esophagectomy for cancer of the esophagus. A regional cancer centre experience. Indian J SurgOncol. 2013 Dec;4(4):332-5.

37. Vrba R, Aujeský R, Stasek M, Vomácková K, Tesaríková J, Hlavácková L, et al. Esophageal cancer results of surgical treatment at the Department of Surgeryl.attheUniversityHospitalOlomouc. RozhlChir.2018;97(7):342-8.

38. Vrba R, Vrana D, Neoral C, Aujesky R, Stasek M, Bohanes T, et al. Complicationsand mortality of surgical therapyforesophageal cancer: 10 years single center experience. Neoplasma. 2018 Sep 19;65(5):799-806.

39. Wang Q, Wu Z, Zhan T, Fang S, Zhang S, Shen G, et al. Comparison of minimally invasive Ivor Lewis esophagectomy and left transthoracic esophagectomy in esophageal squamous cell carcinoma patients: a propensity score-matched analysis. BMC Cancer.2019May27;19(1):500.

40. YekebasEF, SchurrPG, KaifiJT, LinkBC, KutupA, MannO, etal.Effectiveness ofradicalen-bloc-esophagectomycompared totranshiatalesophagectomy in squamous cell cancer of the esophagus is influenced by nodal micrometastases. J SurgOncol. 2006 Jun 1;93(7):541-9. 